\title{
A cross-sectional survey of Aedes aegypti immature abundance in urban and rural household containers in central Colombia
}

Hans J. Overgaard ${ }^{1 *}$, Víctor Alberto Olano², Juan Felipe Jaramillo², María Inés Matiz², Diana Sarmiento², Thor Axel Stenström ${ }^{3}$ and Neal Alexander ${ }^{4}$

\begin{abstract}
Background: Aedes aegypti, the major vector of dengue, breeds in domestic water containers. The development of immature mosquitoes in such containers is influenced by various environmental, ecological and socioeconomic factors. Urban and rural disparities in water storage practices and water source supply may affect mosquito immature abundance and, potentially, dengue risk. We evaluated the effect of water and container characteristics on A. aegypti immature abundance in urban and rural areas. Data were collected in the wet season of 2011 in central Colombia from 36 urban and 35 rural containers, which were either mosquito-positive or negative. Immature mosquitoes were identified to species. Data on water and container characteristics were collected from all containers.
\end{abstract}

Results: A total of 1452 Aedes pupae and larvae were collected of which $81 \%$ were A. aegypti and 19\% A. fluviatilis. Aedes aegypti immatures were found in both urban and rural sites. However, the mean number of $A$. aegypti pupae was five times higher in containers in the urban sites compared to those in the rural sites. One of the important factors associated with A. aegypti infestation was frequency of container washing. Monthly-washed or never-washed containers were both about four times more likely to be infested than those washed every week. There were no significant differences between urban and rural sites in frequency of washing containers. Aedes aegypti immature infestation was positively associated with total dissolved solids, but negatively associated with dissolved oxygen. Water temperature, total dissolved solids, ammonia, nitrate, and organic matter were significantly higher in urban than in rural containers, which might explain urban-rural differences in breeding of A. aegypti. However, many of these factors vary substantially between studies and in their degree of association with vector breeding, therefore they may not be reliable indices for vector control interventions.

Conclusions: Although containers in urban areas were more likely to be infested with A. aegypti, rural containers still provide suitable habitats for $A$. aegypti. Containers that are washed more frequent are less likely to produce $A$. aegypti. These results highlight the importance of container washing as an effective vector control tool in both urban and rural areas. In addition, alternative designs of the highly productive washbasins should continue to be explored. To control diseases such as dengue, Zika and chikungunya, effective vector breeding site control must be implemented in addition to other interventions.

Keywords: Aedes aegypti, Immature stages, Household water container, Dengue, Mosquito

\footnotetext{
* Correspondence: hans.overgaard@nmbu.no

${ }^{1}$ Faculty of Science and Technology, Norwegian University of Life Sciences,

Ås, Norway

Full list of author information is available at the end of the article
} 


\section{Background}

Arboviruses, such as dengue, Zika and chikungunya, are transmitted by mosquitoes of the genus Aedes, especially Aedes aegypti (L.). This species preferentially breeds in man-made water containers in close proximity to human habitations [1]. The risk of dengue transmission increases with rapid, unplanned, and unregulated urban development, poor water storage practices, and unsatisfactory sanitary conditions [1]. These factors are likely to affect the risk of Zika and chikungunya transmission, although the former can also be transmitted sexually [2]. Dengue fever is rapidly spreading globally [3]; approximately 2.5 billion people live in risk areas and an estimated 390 million infections occur annually in more than 100 countries [3]. The annual number of deaths from dengue has been estimated at $\sim 22,000$, mainly among children [4]. Zika has received much attention due to recent outbreaks, starting in Brazil in 2015, resulting in microcephaly in babies. Zika is continuously spreading to areas with competent vectors and currently, at least 84 countries and territories have reported vector-borne Zika virus transmission [5]. The first Zika cases recorded in Colombia were in 2015, when more than 11,700 cases were notified (Boletín Epidemiológico Semanal, Instituto Nacional de Salud, http://www.ins. gov.co). Chikungunya has been identified in over 60 countries, with recent outbreaks in the Indian Ocean, India, southeast Asia and Latin America [6]. Chikungunya can cause severe joint pains, with fever, muscle pain, headaches and other symptoms. In Colombia, local transmission of chikungunya was first identified in 2014, followed by an outbreak with close to 100,000 people being infected and at least eight deaths recorded [7].

Dengue is generally considered an urban disease, but is also of importance in rural areas (e.g. [8, 9]). In LatinAmerica, $A$. aegypti is expanding into peri-urban and rural areas [10-16]. Aedes aegypti has a very limited flight range [17], therefore mosquitoes most likely disperse passively along human transportation networks, e.g. hitchhiking in cars, buses and boats [14]. A distinction between disease in urban and rural areas is often not apparent. A person might become infected in a rural area, but disease symptoms can appear and diagnosis be made in an urban area and vice versa. Regular human movement between rural and urban areas compounds disease records and source of infection. Definitions of "urban" and "rural" differ in both time and place and may not be directly comparable, for example as illustrated by the Urban-Rural Classification Scheme for Counties US National Center for Health Statistics [18] or the WHO/UNICEF Joint Monitoring Programme (JMP) which monitors annual progress on sanitation and drinking water [19].

Mosquito productivity depends on various factors, such as the nutritional quality of the larval environment [20], container type [21, 22], surrounding environmental conditions [23], and climate and seasonality [24, 25]. In addition, socioeconomic factors, such as household size, income, education, water storage practices, and solid waste management, may affect vector presence and abundance [26, 27]. Mosquito abundance is potentially lower in higher socioeconomic strata than in lower strata [26] and in premises in good conditions (assessed by house condition, tidiness of the yard, and degree of shading) [28, 29].

A higher number of dengue cases in urban compared to rural areas may be explained by differences in human and mosquito population densities and higher likelihood of human-mosquito contact (e.g. discussed in [8]). However, higher risk in urban settings could also be partly explained by differences in container characteristics and domestic water management and hence mosquito productivity. In 2012, an estimated 79\% of the world's urban population had piped water into their houses, compared to only $33 \%$ in rural areas [30], suggesting that a higher proportion of rural households store water than urban households. It is not clear whether there are differences in mosquito productivity between urban and rural containers. Knowing this could help authorities plan control activities.

In Colombia, $A$. aegypti is present in all departments (first-level administrative subdivision) and up to an altitude of at least $2300 \mathrm{~m}$ above sea level [31]. The most productive and permanent containers are ground tanks and concrete washbasins for laundry (albercas), whereas other containers, such as bottles, cans, tires, etc., are only productive during the rainy season and produce low numbers of pupae [21, 32, 33]. In Colombia, larval control, such as the application of the organophosphate temephos, is generally only practiced in epidemic situations. For routine control, communities are recommended to keep containers covered and clean [34].

Mosquito oviposition behavior is affected by visual, tactile, and olfactory cues, including physico-chemical properties of the water [35]. Oviposition by female $A$. aegypti is often argued to take place in containers with clean water; however, this is not always true as A. aegypti has been found to breed in polluted water and raw sewage $[36,37]$. The number of immatures per container is not homogeneously distributed [38], indicating that female mosquitoes prefer to oviposit in specific types of containers. Such containers may be more epidemiologically important than other container types [38, 39]. The typical skip oviposition behavior observed in female $A$. aegypti [40] may be modulated by the presence and abundance of conspecifics [41, 42] and by the availability of breeding sites [43]. Larval mosquito diets mainly consist of bacteria and detritus [44, 45]. Availability of nutrition in containers is critical for mosquito development and may affect 
mosquito size and survival $[46,47]$, which in turn may affect vector-borne disease transmission outcome [48, 49]. For example, $A$. aegypti-positive containers have been found to have more dissolved nitrogen ions than negative containers [50]. It is likely a combination of the oviposition behavior of female mosquitoes and the quality of the breeding habitat that influences the importance of certain containers over others.

The objectives of this study were to determine whether $A$. aegypti immature production differed in urban and rural areas and what factors were associated with $A$. aegypti immature production in mosquito-infested containers in urban and rural areas.

\section{Methods}

\section{Study area}

The study was carried out in urban and rural sites in Anapoima municipality, Cundinamarca, central Colombia (centered at 4.551271N, 74.536436W) (Fig. 1). In 2011,
Anapoima had a projected population of approximately 12,500 inhabitants (based on the general census in 2005), with $57 \%$ in rural areas [51]. The total population in Anapoima town (cabecera municipal) in 2011 was $~ 5300$ with a population density of $\sim 739$ persons $/ \mathrm{km}^{2}$. The corresponding figures for the rural area were $\sim 7100$ and $\sim 54$ persons $/ \mathrm{km}^{2}$. The total municipal area is $124.2 \mathrm{~km}^{2}$ at an average altitude of $700 \mathrm{~m}$ above sea level (masl), an average annual temperature of $26{ }^{\circ} \mathrm{C}$ and rainfall of $1300 \mathrm{~mm}$. The main economic activities are agriculture (sugar cane, coffee, fruit and livestock) and tourism. The natural vegetation consists of dry tropical forest, premontane and lower montane moist forests.

Official criteria from the National Administrative Department of Statistics, Colombia were used to distinguish between urban and rural study sites [52]. An urban area, according to these criteria, is characterized by buildings and adjacent structures grouped into blocks bounded by streets and avenues; the presence of essential public

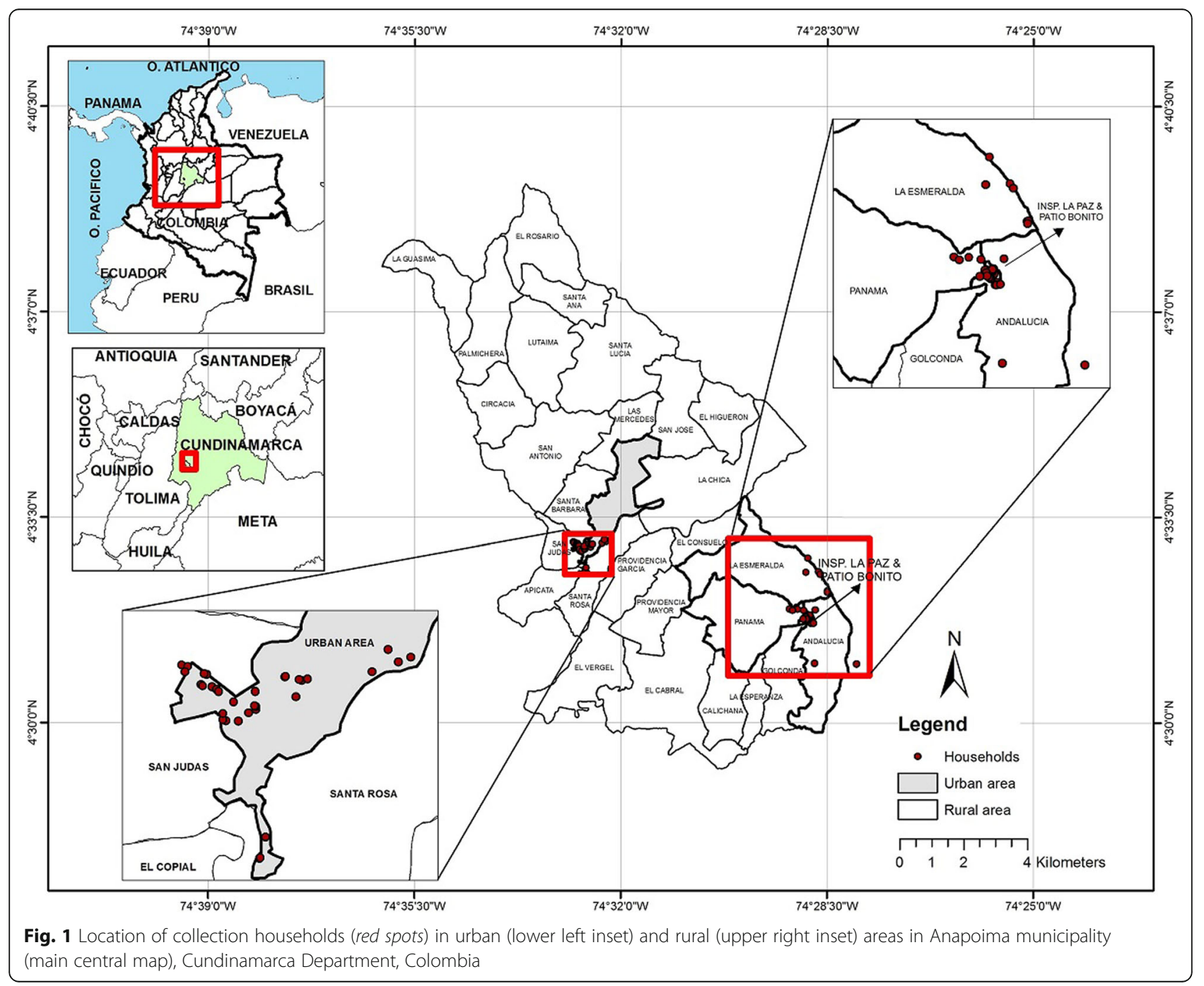


services such as water, sewage, electricity, hospitals, schools; and the seat of the municipal administration. A rural area is characterized by housing and dispersed farms without a layout of streets, generally lacking of public services and other facilities featured in urban areas. Rural areas also include so-called inspecciones, which are small concentrations of houses more densely populated than the dispersed areas. The rural area in Anapoima has a lower socio-economic level than the urban area, with $36 \%$ of the population classified as poor and $13 \%$ of those $>15$ years old being illiterate; the corresponding figures for the urban area were 21 and 5\%, respectively [53]. The criteria used to define poverty were if people lived in overcrowded conditions ( $>3$ people/room), without piped water connection or sanitary facilities, in households with high economic dependence (i.e. $>3$ persons/employed household member), low education level of household head $(<2$ years of primary education), and children aged between 6 and 12 years not attending school [53]. Aerial images from Google Earth and environments surrounding some of the study households are shown in Fig. 2.
Study sites within the urban and rural areas were selected based on $A$. aegypti infestation registers from Anapoima Secretary of Health and unpublished data of the Instituto de Salud y Ambiente, Universidad El Bosque (Informe Final. Resultados del diagnóstico del proyecto Prevención del dengue y control del $A$. aegypti en el área rural del municipio de Anapoima, Cundinamarca, 2011). Sites with highest infestation rates in the urban area were selected; in 2010 those sites had a Container Index of $14.3 \%$ and a Breteau index of 15 (pers. comm. José Fernando Sánchez. Coordinador Programa ETV y Zoonosis, Secretaría de Salud, Gobernación de Cundinamarca). Thus, six neighborhoods were selected in the urban area (Centro, San José, Las Palmas, Asopobin, La Estrella and Nueva Colombia). These six neighborhoods had a total of 292 households at the time of the study. In the rural study area, three adjacent sites were selected: Inspección La Paz (total 52 households or 26 houses), Patio Bonito (total 45 households or 23 houses), and Andalucía (total 143 houses). Entomological data from 2010 collected in the rural areas of Anapoima showed a House Index of 5\% in Andalucia and 18\% in La

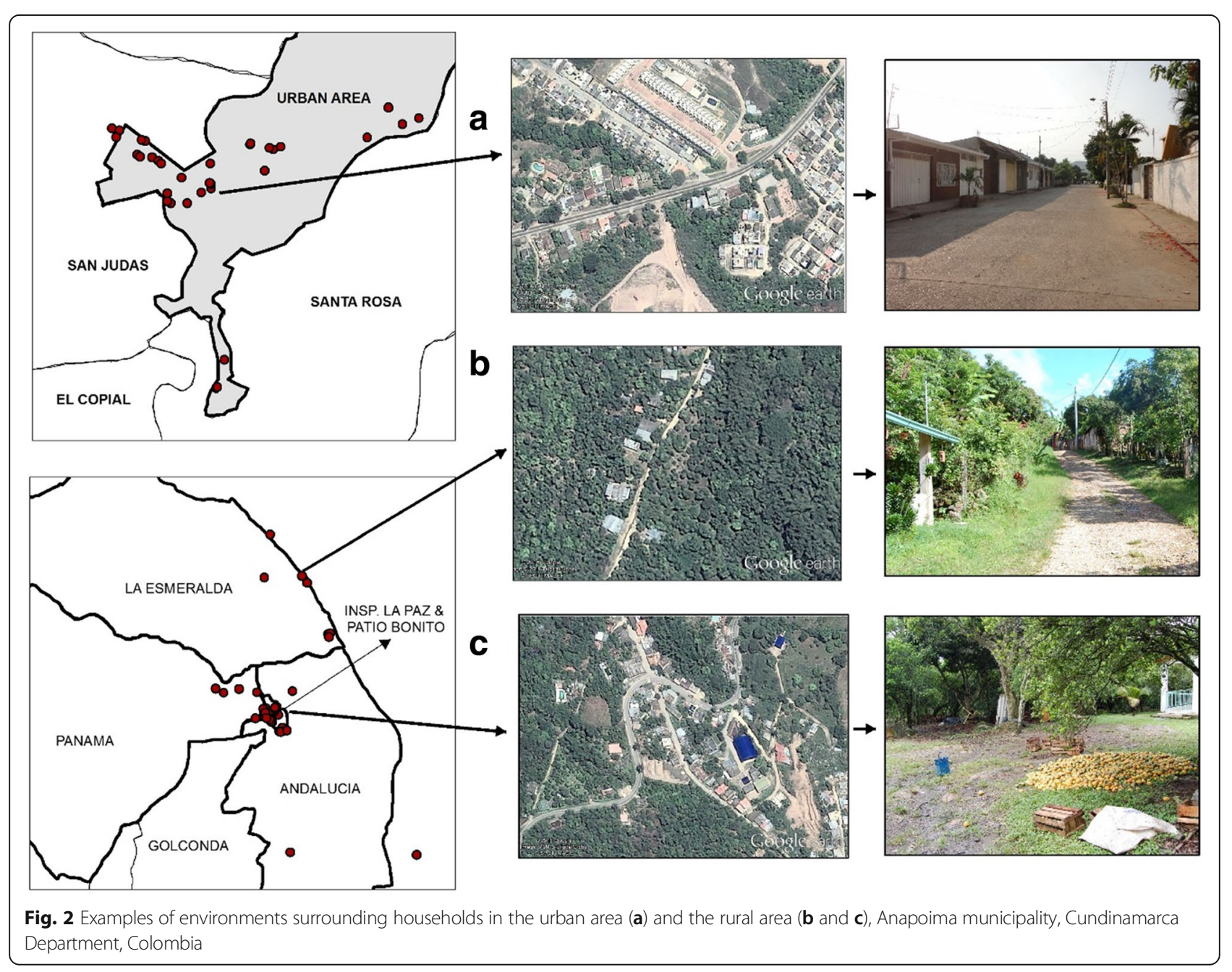


Paz and Patio Bonito each. The average altitude was 697 (range: 636-743) masl for the urban households and 1038 (range: 941-1124) masl for the rural ones. Routine larval control consists of cleaning and covering of containers, whereas temephos is applied during epidemics [34].

\section{Study design and sample size}

This is a cross-sectional study with the water storage container as the unit of analysis. The sample size was determined to be at least 34 containers representing the urban and rural area, respectively (a total of at least 68 containers) giving $80 \%$ power to detect a ratio of means of 2 , with negative binomial $k$ parameter of 2 and significance level of 5\% [54]. In the urban site, 33 of 292 houses were selected for collections. In the rural sites, 37 of 192 houses were selected, 29 in Patio Bonito and 8 dispersed houses in La Paz and Andalucía combined.

\section{Data collection}

Field staff randomly selected houses in the two areas to complete the calculated container sample size. The aim was to sample one mosquito-positive and one mosquitonegative container from each selected household. All containers were inspected visually, and each was considered positive if either larvae or pupae were present. Then, in households with at least one mosquito-positive and at least one mosquito-negative container, one of each type was sampled. In households with only positive containers, one container was sampled. If two or more containers were positive, then the one with highest mosquito infestation was selected, based on visual inspection of the presence of larvae and pupae. In households with only negative containers, the first available container was sampled. Eggs were not included in the collection framework. Data on the total number of containers present in each inspected household and the number of positive containers in each household were not collected. Data were only collected from two types of containers, ground tanks (low tanks) and concrete washbasins for laundry (albercas), because these are the most important and productive containers identified in Colombia [33]. Based on our unpublished data from rural areas in Anapoima, we also found the same types of containers being the most infested (Instituto de Salud y Ambiente, Universidad El Bosque. Informe Final. Resultados del diagnóstico del proyecto Prevención del dengue y control del $A$. aegypti en el área rural del municipio de Anapoima, Cundinamarca, 2011).

Before inspecting containers, residents were first asked if any container had been treated in any way. None of the collection containers were reported as being treated by any chemical or cleaned during the last $72 \mathrm{~h}$. In total, 71 domestic water containers were included, of which 37 were mosquito-positive and 34 mosquito-negative. Of the 71 containers, 36 were located in the urban area and 35 in the rural area. Collections were carried out in October-December 2011 (rainy season). In addition, the altitude of the household was measured using a GPS handheld unit.

\section{Mosquitoes}

All mosquito immatures (pupae and larvae) of the genus Aedes were collected from the identified positive containers using glazed soup ladles or sweep nets. In addition, a sample of immatures identified to other genera were collected using ten dips from different parts of the container, the total number of larvae counted, and approximately $10 \%$ stored for later identification. Collected larvae and pupae were kept in plastic vials with $70 \%$ ethanol. Taxonomic identification of mosquitoes was carried out in the entomology laboratory of the Lazos de Calandaima Foundation in Anapoima using appropriate taxonomic keys [55-57].

\section{Container characteristics}

Data on the following container characteristics were collected: site (rural, urban); type (ground tank, wash basin); location (outdoors, indoors); material (plastic, cement, metal); immediate water source (village pipe, municipal pipe, rain only, rain + village pipe, rain + municipal pipe, village pipe + river + spring); use (washing + cleaning, multiple uses including drinking, multiple uses excluding drinking, drinking only, plants); lid on container (none, effective lid, ineffective lid); reported frequency of washing (weekly, monthly, never); whether in shade (yes, partial, no); and whether under roof (yes, partial, no).

\section{Water characteristics}

For each container, data on water temperature $\left({ }^{\circ} \mathrm{C}\right), \mathrm{pH}$, electrical conductivity $(\mathrm{EC}, \mu \mathrm{S} / \mathrm{cm})$ and total dissolved solids (TDS, mg/l) were collected in situ using a $\mathrm{HACH}$ multiparameter (sensION+ Portable pH \& EC field kit, with MM150 meter, 5059 electrode). Thereafter, a composite water sample consisting of 2-6 subsamples (depending on water level), including central and peripheral parts of containers and biofilms on container walls, amounting to $300-2000 \mathrm{ml}$, was taken from each container. Samples were stored on ice and conserved according to prescribed methods [58]. The content of ammonia $\left(\mathrm{NH}_{4}^{+}, \mathrm{mg} / \mathrm{l}\right)$, phosphate $\left(\mathrm{PO}_{4}^{3-}, \mathrm{mg} / \mathrm{l}\right)$, nitrate $\left(\mathrm{NO}_{3}^{-} \mathrm{mg} / \mathrm{l}\right)$, dissolved oxygen ( $\left.\mathrm{DO}, \mathrm{mg} / \mathrm{l}\right)$, and total suspended solids (TSS, mg/l) were analyzed by Daphnia Laboratory, Bogotá, Colombia (certified laboratory by IDEAM, Ministry of Environment and Sustainable Development, Res. 0347/2010 and 0710/2012). The visible presence of algae (yes/no), organic matter (leaves, etc.) (yes/no), and macroinvertebrates (unspecified aquatic insects, crustaceans, etc.) (yes/no) was assessed in the field. 
Water samples for bacterial abundance assessment were prepared in the laboratory for subsequent microbial counts using fluorescent microscopy. Briefly, three sample dilutions $(1: 10,1: 20,1: 40)$ were prepared to a final volume of $100 \mathrm{ml}$. Two duplicates of $10 \mathrm{ml}$ of each dilution were placed in 27-well glass plates, passed over a flame for fixing bacteria and stained with $1000 \mathrm{mg} / \mathrm{ml}$ acridine orange solution for $3 \mathrm{~min}$. An oil immersion of samples were observed under $100 \times$ objective under UV light with a fluorescence microscope (A2 AxioVision Carl Zeiss Microscopy, LLC). Photos of 20 microscope fields per well for each replica were taken and the number of bacterial cells per photo were determined by indirect counting using Scion Image program (Beta 4.0.2, Scion Corporation) accounting for well area, dilution and initial volume. Results were expressed as the total number of bacterial cells per milliliter of sample. Fluorescent microscopy was done in the Laboratory of Virology, Universidad El Bosque, Bogotá, Colombia.

\section{Data analysis}

Descriptive analyses were used to explore the data. Analysis of abundance was based only on mosquito-positive containers. Mosquito-negative containers are not informative on abundance since the study design ensured that their number equaled that of the mosquito-positive containers. A zero-truncated negative binomial model was used to compare A. aegypti larval abundance between urban and rural sites. This model was chosen because all mosquito-negative containers had zero larvae. Differences in A. aegypti pupal abundance in mosquito-positive containers between sites were analyzed using a standard (non-truncated) negative binomial model, because some positive containers did not have pupae. A zero-truncated negative binomial model was also used to compare larval abundance of non-Aedes species, mainly Culex species, between urban and rural sites.

Before logistic regressions were carried out, nonnormally distributed continuous variables were $\log _{10^{-}}$ transformed, then bivariate analyses, using Chi-square test and Student's t-test for categorical and continuous variables, respectively, were used to select variables (with $P<0.1$ ). Pearson's correlation coefficients were then calculated among remaining variables to assess collinearity. For variables with a correlation $>0.5$ only one was kept, e.g. $\operatorname{logEC}$ was removed due to high correlation with $\log$ TDS $(r=0.936)$. Finally, simple and multivariable (backward stepwise) logistic regression analyses were done using container and water characteristics variables as predictors and Aedes larvae- or pupae-positivity as response variables. Differences in container and water characteristics between urban and rural sites were analyzed by Chisquare tests and t-tests. Data were analyzed using Stata version 14.1.

\section{Results}

\section{Aedes aegypti productivity in mosquito-positive} containers

A total of 1452 Aedes immatures (pupae and larvae) were collected of which 1172 (80.7\%) were A. aegypti and 280 (19.3\%) A. fluviatilis (Lutz). Other species present in the collected samples were Culex quinquefasciatus (Say), Cx. coronator (Dyar \& Knab), Cx. corniger (Theobald), Limatus durhamii (Theobald), and other Culex spp. not identified to species.

Among positive containers, infestation of $A$. aegypti larvae was 14.3 larvae/container in urban areas and 11.3 larvae/container in rural areas, and this difference was not statistically significant (Table 1 ). The mean density of $A$. aegypti pupae was higher in urban than in rural areas (6.2 vs 1.2 pupae/container), corresponding to a ratio of means more than five times higher $(P=0.030$, Table 1). In contrast, the mean number of other larvae, i.e. non-Aedes larvae (generally Culex), was $76 \%$ lower than in the rural area (rural: 3.1 larvae/container vs urban: 0.6 larvae/container $)(P=0.032$, Table 1$)$.

\section{Factors associated with $A$. aegypti immature production}

Comparing positive and negative containers, the most important factors individually associated with $A$. aegypti presence were frequency of washing the container $\left(\chi^{2}=6.16\right.$, $d f=2, P=0.046), \log _{10}$ TDS $\left(t_{(69)}=-2.67, P=0.005\right)$, DO $\left(t_{(69)}=2.08, P=0.021\right)$, and $\mathrm{pH}\left(t_{(69)}=-1.81, P=0.037\right)$. Results from the univariate and multivariate logistic regression models are shown in Tables 2 and 3, respectively. Containers reported to be washed every month or never washed had each four times higher odds of $A$. aegypti infestation compared to containers with a weekly washing (Table 3 ). In the univariate analysis, TDS was positively associated with $A$. aegypti infestation (univariate: $P=0.013$ ), while dissolved oxygen content was negatively associated (univariate: $P=0.052$; multivariate: $P=0.026$ ). $\mathrm{pH}$ was not significantly associated with mosquito infestation (univariate: $P=0.089$ ). The stepwise multivariate analysis yielded a model with frequency of washing and dissolved oxygen both statistically significantly associated with infestation.

\section{Container and water characteristics in urban and rural sites}

Container characteristics were similar between the urban and rural sites. Most were washbasins without lids, located outdoors and washed on a weekly or monthly basis. The main significant differences between urban and rural sites were in container materials, source of water, and presence of organic material (see Table 4 for details). The altitude of the rural sites was significantly higher than the urban sites (Table 5). Compared to the rural containers, the water in the urban containers was significantly warmer, had a higher electrical conductivity (EC) and higher concentrations of total dissolved solids 
Table 1 Number of specimens collected in urban and rural containers and ratios of means (95\% confidence intervals, Cl) from negative binomial regression analyses of mosquito immature abundance in urban compared to rural sites in Anapoima municipality, Colombia

\begin{tabular}{|c|c|c|c|c|c|c|c|}
\hline Variable & Level & No. specimens (\%) & No. containers & Ratio of means & $95 \% \mathrm{Cl}$ & $Z$ & $P$ \\
\hline \multirow[t]{3}{*}{ A. aegypti larvae } & Rural & $395(43)$ & 37 & 1 & & & \\
\hline & Urban & $514(57)$ & & 1.26 & $0.48-3.36$ & 0.47 & 0.639 \\
\hline & Sum & $909(100)$ & & & & & \\
\hline \multirow[t]{3}{*}{ A. aegypti pupae } & Rural & $41(16)$ & 18 & 1 & & & \\
\hline & Urban & $222(84)$ & & 5.13 & $1.18-22.37$ & 2.18 & 0.030 \\
\hline & Sum & $263(100)$ & & & & & \\
\hline \multirow[t]{3}{*}{ Other larvae } & Rural & $109(83)$ & 18 & 1 & & & \\
\hline & Urban & $23(17)$ & & 0.24 & $0.06-0.89$ & -2.14 & 0.032 \\
\hline & Sum & $132(100)$ & & & & & \\
\hline
\end{tabular}

(TDS), ammonium and nitrate, but a lower concentration of total suspended solids (TSS) (Table 5).

\section{Discussion}

Aedes aegypti bred in containers in both urban and rural settings, but the productivity of pupae was higher in urban containers, where the odds of pupal infestation was five times higher $(P=0.03)$. In this study, mosquitoes were only collected from ground tanks and washbasins, because these are most productive containers [32]. Other containers, such as rubbish and tires, etc. may produce low numbers of mosquitoes, but usually only in the rainy season [21, 33]. Although these collections were done in the rainy season (October-December), the main mosquito producing permanent breeding habitats would be the most important to determine differences between urban and rural mosquito production. A limitation of the study design, however, was that containers were selected on the basis of being positive or negative, with equal numbers of each being included. Hence, we could not compare the proportion of Aedes-positive houses or containers, between urban and rural areas, in terms of indices such as the Breteau. The numbers of positive or negative containers which were inspected,

Table 2 Odds ratios of factors associated with A. aegypti immature infestation in Anapoima municipality, Colombia, using univariate logistic regression ( $n=71$ observations)

\begin{tabular}{llll}
\hline Variable & Level & OR (95\% Cl) & $P$ \\
\hline $\begin{array}{l}\text { Frequency of washing } \\
\text { container }\end{array}$ & Weekly & 1 & \\
& Monthly & $3.45(1.16-10.29)$ & 0.026 \\
& Never & $3.60(0.93-13.95)$ & 0.064 \\
$\begin{array}{l}\text { Total dissolved solids, } \\
\text { TDS (log10 mg/l) }\end{array}$ & $8.60(1.57-46.84)$ & 0.013 \\
$\begin{array}{l}\text { Dissolved oxygen, DO } \\
\text { (mg/l) }\end{array}$ & $0.59(0.34-1.00)$ & 0.052 \\
pH & & $2.01(0.91-4.42)$ & 0.089 \\
\hline
\end{tabular}

Abbreviations: OR odds ratio; $95 \% \mathrm{Cl} 95 \%$ confidence interval but not included to preserve balance, could have been used as weights in a more informative analysis, but these numbers were unfortunately not recorded.

Considering the higher density of people, houses, and water storage containers in urban compared to rural settings, it is likely that $A$. aegypti productivity and dengue risk are higher in the former setting. Nevertheless, the current data show that $A$. aegypti rural breeding is substantial and should not be ignored. Dengue transmission and outbreaks, as well as DENV infected mosquitoes are not that uncommon in rural areas [9, 16, 59]. Adult $A$. aegypti collected in 2012-2013 in the rural study area showed high DENV infection rates, with a pool positivity rate of $62 \%$ and estimated individual mosquito infection rate of about $4 \%$ [16]. These facts indicate that rural areas are at substantial risk of dengue, and therefore merit regular entomological surveillance to detect locations for effective vector control interventions.

One of the most important factors associated with $A$. aegypti infestation was the frequency of container washing, both in urban and rural settings. Containers reported to be washed every month were more than four times more likely to be infested with $A$. aegypti than those reportedly washed every week. Never-washed containers were also four times more likely to be infested than those washed every week. This suggests that cleaning washbasins and low tanks on a regular basis is an

Table 3 Odds ratios of factors associated with A. aegypti immature infestation in Anapoima municipality, Colombia, using multivariate logistic regression ( $R^{2}=0.124 ; n=71$ observations)

\begin{tabular}{llll}
\hline Variable & Level & OR $(95 \% \mathrm{Cl})$ & $P$ \\
\hline Frequency of washing container & Weekly & 1.00 & \\
& Monthly & $4.23(1.31-13.68$ & 0.016 \\
& Never & $4.55(1.09-18.96)$ & 0.037 \\
Dissolved oxygen, DO (mg/l) & & $0.51(0.28-0.92)$ & 0.026 \\
\hline
\end{tabular}

Abbreviations: OR odds ratio; $95 \% \mathrm{Cl} 95 \%$ confidence interval 
Table 4 Container and water characteristics (categorical variables) in urban and rural sites in Anapoima municipality, Colombia, OctoberDecember 2011. Both mosquito-positive and negative containers are included. Differences between urban and rural sites were tested using Chi-square test

\begin{tabular}{|c|c|c|c|c|c|}
\hline \multirow[t]{2}{*}{ Variable } & \multirow[t]{2}{*}{ Value } & \multirow{2}{*}{$\begin{array}{l}\text { Urban (\%) } \\
n=36\end{array}$} & \multirow{2}{*}{$\begin{array}{l}\text { Rural (\%) } \\
n=35\end{array}$} & \multirow[t]{2}{*}{ Chi-square } & \multirow[t]{2}{*}{$P$} \\
\hline & & & & & \\
\hline \multirow[t]{2}{*}{ Container type } & Wash basin (alberca) & 52.8 & 60.0 & 0.38 & 0.540 \\
\hline & Ground tank & 47.2 & 40.0 & & \\
\hline \multirow[t]{2}{*}{ Location of container } & Outdoors & 52.8 & 73.5 & 3.22 & 0.073 \\
\hline & Indoors & 47.2 & 26.5 & & \\
\hline \multirow[t]{3}{*}{ Material of container } & Plastic & 33.3 & 20.6 & 6.31 & 0.043 \\
\hline & Cement & 55.6 & 79.4 & & \\
\hline & Metal & 11.1 & 0.0 & & \\
\hline \multirow[t]{6}{*}{ Source of water } & Village pipe & 5.6 & 62.9 & 40.33 & $<0.0001$ \\
\hline & Municipal pipe & 61.1 & 5.7 & & \\
\hline & Rain only & 11.1 & 11.4 & & \\
\hline & Rain + village pipe & 8.3 & 17.1 & & \\
\hline & Rain + municipal pipe & 13.9 & 0.0 & & \\
\hline & Village pipe + river + spring & 0.0 & 2.9 & & \\
\hline \multirow[t]{4}{*}{ Use of water } & Washing + cleaning & 58.3 & 60.0 & 0.32 & 0.956 \\
\hline & Multiple uses, including drinking & 11.1 & 11.4 & & \\
\hline & Multipe uses, excluding drinking & 25.0 & 25.7 & & \\
\hline & Drinking only & 5.6 & 2.9 & & \\
\hline \multirow[t]{3}{*}{ Lid status } & Effective lid & 22.2 & 8.8 & 2.42 & 0.299 \\
\hline & None & 58.3 & 70.6 & & \\
\hline & Ineffective lid & 19.4 & 20.6 & & \\
\hline \multirow[t]{3}{*}{ Frequency of container washing } & Weekly & 27.8 & 48.6 & 3.94 & 0.140 \\
\hline & Monthly & 52.8 & 31.4 & & \\
\hline & Never & 19.4 & 20.0 & & \\
\hline \multirow[t]{3}{*}{ Location in shade } & Yes & 50.0 & 38.2 & 1.08 & 0.584 \\
\hline & No & 16.7 & 23.5 & & \\
\hline & Partial & 33.3 & 38.2 & & \\
\hline \multirow[t]{3}{*}{ Location under roof } & Yes & 55.6 & 55.9 & 2.58 & 0.275 \\
\hline & No & 13.9 & 26.5 & & \\
\hline & Partial & 30.6 & 176 & & \\
\hline Algae in container & Present & 19.4 & 22.9 & 0.12 & 0.725 \\
\hline Organic material in container & Present & 66.7 & 42.9 & 4.06 & 0.044 \\
\hline Macroinvertebrates in container & Present & 19.4 & 5.7 & 3.02 & 0.082 \\
\hline
\end{tabular}

effective mosquito control activity. The importance of cleaning containers for dengue vector control has been shown in many studies [60-63] and is recommended by WHO [64]. By promoting the use of detergents and/or chlorine and brushing the inside walls of containers, community dengue vector control using these methods has been shown to be effective [65]. In Colombia, the alberca, a square concrete laundry basin, is ubiquitous and very often mosquito-infested $[15,66]$. Most have two sections, one for storing water and the other for washing clothes with horizontal grooves in the concrete. This design makes it difficult to inhibit mosquito breeding. New washbasin designs and technologies could be an effective way to reduce mosquito breeding in settings as those studied here [66].

Other factors of potential importance for $A$. aegypti infestation were the concentration of TDS and DO in water. TDS was positively associated with $A$. aegypti infestation in the univariate model (Table 2), but was not included in the multivariate model (Table 3 ). TDS is 
Table 5 Container and water characteristics (continuous variables) in urban and rural sites in Anapoima municipality, Colombia, October-December 2011. Both mosquito-positive and negative containers are included

\begin{tabular}{|c|c|c|c|c|c|c|}
\hline \multicolumn{2}{|c|}{ Variable } & \multirow{2}{*}{$\begin{array}{l}\text { Urban } \\
25.5(25.1-26.0)\end{array}$} & \multirow{2}{*}{$\frac{\text { Rural }}{22.7(22.3-23.0)}$} & \multirow{2}{*}{$\frac{d f}{69}$} & \multirow{2}{*}{$\frac{t \text {-value }}{-10.36}$} & \multirow{2}{*}{$\frac{P}{<0.00001}$} \\
\hline 1 & Water temperature $\left({ }^{\circ} \mathrm{C}\right)$ & & & & & \\
\hline 2 & $\mathrm{pH}$ & $7.42(7.18-7.66)$ & $7.72(7.50-7.94)$ & 69 & 1.87 & 0.033 \\
\hline 3 & Total dissolved solids, TDS (mg/l) & $100.2(85.6-114.9)$ & $58.7(37.9-79.4)$ & 69 & -5.14 & $<0.00001$ \\
\hline 4 & Electrical conductivity, EC ( $\mu \mathrm{S} / \mathrm{cm})$ & $152.6(128.2-176.9)$ & $91.3(58.2-124.4)$ & 69 & -4.31 & $<0.00001$ \\
\hline 5 & Ammonia, $\mathrm{NH}_{4}(\mathrm{mg} / \mathrm{l})$ & $0.30(0.26-0.33)$ & $0.24(0.20-0.28)$ & 69 & -1.71 & 0.046 \\
\hline 6 & Phosphate, $\mathrm{PH}_{4}(\mathrm{mg} / \mathrm{l})$ & $0.13(0.10-0.17)$ & $0.16(0.11-0.22)$ & 69 & 0.96 & $0.339^{a}$ \\
\hline 7 & Nitrate, $\mathrm{NO}_{3}(\mathrm{mg} / \mathrm{l})$ & $0.42(0.37-0.47)$ & $0.22(0.16-0.29)$ & 69 & -5.49 & $<0.00001$ \\
\hline 8 & Dissolved oxygen, DO (mg/l) & $6.25(5.97-6.53)$ & $5.85(5.42-6.29$ & 69 & -1.56 & $0.124^{a}$ \\
\hline 9 & Total suspended solids, TSS (mg/l) & $8.03(4.80-11.25)$ & $45.86(11.66-82.05)$ & 69 & 4.40 & $<0.00001$ \\
\hline 10 & Number of bacteria ( $\log _{10}$ bacteria /ml) & $5.00(4.81-5.23)$ & $5.06(4.53-5.58)$ & 33 & 0.25 & $0.804^{a}$ \\
\hline 11 & Altitude (masl) & $697.3(689.5-705.1)$ & $1037.9(1022.0-1053.8)$ & 68 & 39.80 & $<0.00001$ \\
\hline
\end{tabular}

Differences in mean values $(95 \% \mathrm{Cl})$ between urban and rural sites were tested using Student's t-test ( $d f=$ degrees of freedom). The results of the t-tests of TDS, $\mathrm{EC}$, $\mathrm{NH}_{4}$, $\mathrm{PH}_{4}, \mathrm{NO}_{3}$, and TSS are based on log10-transformed data, although the urban and rural values presented are the actual means for asier comparisons

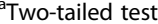

the sum of inorganic salts and small amounts of organic matter dissolved in water and is thus a measure of the combined content of all inorganic and organic substances contained in a liquid in molecular, ionized or micro-granular suspended form. Such water may contain particles which constitute food and nutrients for developing larvae [20,44]. The mean TDS values in urban and rural containers (urban: $100 \mathrm{mg} / \mathrm{l}$; rural: $59 \mathrm{mg} / \mathrm{l}$, Table 5) were low in comparison to other studies. For example, the TDS in natural stream water from mountain sites and valley sites were $\sim 200 \mathrm{mg} / \mathrm{l}$ and 400 $600 \mathrm{mg} / \mathrm{l}$, respectively [67, 68]. Likewise, TDS in Aedes breeding habitats in West Bengal, India were all higher than 200 ppm [69], i.e. close to stream water values. This could be explained by more variable types of breeding habitats included in the India study, such as earthen containers, coconut shells, tires, tree holes, and plastic containers. Also in these containers, there was a significant positive correlation between TDS and larval density [69]. It may, therefore, be that TDS is a contributing factor to breeding success, but, when other factors are taken into consideration (multivariate results), this factor may become less important.

DO was negatively associated with $A$. aegypti infestation in both models (Tables 2 and 3), but there were no differences in DO levels between urban and rural sites (Table 5). Ma et al. [70] also found a significantly negative association between DO and overall larval abundance in Chinese urban river systems, although these larvae mainly consisted of Culex species. On the other hand, A. aegypti has been observed to oviposit and develop normally in raw sewage with low levels of dissolved oxygen, suggesting a wide tolerance spectrum [36]. However, this is probably more the exception than the norm. It is also worth noting that DO fluctuates on a daily and seasonal basis, sometimes as much as from 1 to $20 \mathrm{mg} / \mathrm{l}$, based on variations in natural processes such as diffusion, aeration, photosynthesis, respiration, decomposition, temperature, and air pressure [71]. The magnitude of such variations in water storage containers is unclear. Nevertheless, it is reasonable to assume that lower oxygen content reduces the suitability for mosquito immature development, as has been shown for several mosquito species [72] and other aquatic invertebrates [73].

The association between non-Aedes larvae (mostly Culex) and urban/rural settings was opposite to that of Aedes mosquitoes, with urban containers less likely to be infested. The reasons for this are unclear. Culex species are generally considered to be more associated with contaminated waters, relative to $A$. aegypti [74]. In this study, the water in the urban containers seemed to be more contaminated than the rural containers, with higher values of EC and TDS, and higher content of ammonium and nitrate, which, at least, would indicate a higher degree of particulate matter and organic material. However, the overall levels of TDS, EC, and nitrate were low compared to other studies $[68,75,76]$ and differences in these parameters do not explain all of the variation in Culex infestation. Culex spp. are ubiquitous mosquito species adapted to many types of environments, such as rural, urban, clean and contaminated water (e.g. [77]) and might have adapted well in this rural setting. Our data do not clearly explain why Culex spp. were more abundant in these rural settings.

Water temperature, another important factor for mosquito metabolism and development, was significantly higher in urban than in rural containers. Water temperature is affected by the surrounding ambient temperature, which is higher at lower altitudes and is also affected by urban settings, due to human activities 
and modification of land surfaces, a phenomenon called urban heat island [78]. The urban households in this study were generally located at a lower altitude than the rural households, potentially affecting ambient, as well as water temperatures. Mosquito development is faster in warm water than in cold water and maximum survival rates being at $20-30{ }^{\circ} \mathrm{C}$ [79]. The temperatures in this study were within these limits. Higher ambient and water temperatures may affect mosquito population dynamics, potentially reducing development times and increasing mosquito production [80-83]. Water temperature could be expected to affect both Aedes and Culex production similarly, but this was apparently not the case. Nevertheless, these results show that vector control is important in rural as well as urban areas, not only for dengue, but also for other vector-borne diseases, such as those transmitted by Culex and other genera. For example, Olano et al. $[10,15]$ found several potentially important mosquito vector genera, in addition to Aedes, in rural schools in the same study area.

As the characteristics of the water are important to immature development, they also affect the oviposition behavior of female mosquitoes. Ovipositing $A$. aegypti are affected by the bacterial composition of water [84], presence of conspecifics [41], and other potential cues from the water and the container in order to maximize survival of offspring. Such factors may explain the skip oviposition behavior of this mosquito species [40]. It is possible that these small, though significant physicochemical differences could have favored $A$. aegypti production in urban over rural containers. On the other hand, another study from India found opposite results to ours, with a negative correlation between TDS and larval density and a positive correlation between DO and larval density [75]. This suggests that it is difficult to find universal agreement on specific physicochemical characteristics that are most important for $A$. aegypti breeding success and production. Risk of dengue has many other determinants including adult vector density and production, serotype circulation, human population density, movement, behaviors and immunity. Therefore, although control of vector breeding sites will remain an important part in arbovirus control, it alone may not reduce the disease burden of arboviruses, such as dengue, Zika, and chikungunya.

\section{Conclusions}

Mosquito vectors, such as $A$. aegypti and Culex species breed in containers in both urban and rural settings, but urban containers were more likely to be infested with $A$. aegypti immatures than rural containers. In contrast, rural containers were more likely to be infested with Culex immatures. It should be noted though, that only ground tanks and washbasins were sampled in this study, as they currently are considered the most productive containers in both urban and rural areas. As mosquito ecological relationships are dynamic, such assumptions may change due to environmental and climate change. Containers that were washed more frequently (weekly or monthly) were less likely to be infested with $A$. aegypti than containers that were never washed. Aedes aegypti immature infestation was positively associated with total dissolved solids, but negatively associated with dissolved oxygen. Recommendations based on these results are that vector control should not only be carried out in urban areas, which is often the case, but also be implemented in rural areas. A suitable and effective vector control option in these settings is frequent container washing. Development of alternative designs of the highly mosquito productive washbasins in Colombia should continue to be explored.

\section{Acknowledgements \\ We thank the mayors' offices, the health and education secretaries of Anapoima municipality for their collaboration. We are grateful for the assistance of the fieldworkers: Nancy Herrera, Laura Hernández, Laura Cabezas, Sergio Salas, Maria Fernanda Molina and Ximena Roncancio. We gratefully acknowledge the support and assistance of Dr. Miguel Otero, Director of Research, Universidad El Bosque, Bogotá, Colombia. Thanks also to Lina María Marín Gallón, supervised by Jaime Castellanos at the Laboratory of Virology, Universidad El Bosque for doing the fluorescent microscopy. Laura Cabezas produced the maps in Figs. 1 and 2.}

\section{Funding}

This work was funded by the Research Council of Norway (Project no. 201349), the Fundación Lazos de Calandaima, Colombia, and Universidad El Bosque, Colombia.

\section{Availability of data and materials}

The data supporting the conclusions of this article are included within the article. Raw data are available from the corresponding author on request.

\section{Authors' contributions}

HJO: conception, design, analysis and interpretation. VAO and JFJ: conception, design, analysis, execution and interpretation. MIM and DS: execution and interpretation. TAS: conception and interpretation. NA: design, analysis and interpretation. All authors were involved in the drafting, reviewing and revising the manuscript. All authors approved the final manuscript.

\section{Ethics approval and consent to participate}

This study was part of a larger cluster-randomized trial [56] for which ethical approval was given by the Comité Institucional de Ética en Investigaciones de la Universidad El Bosque, Bogotá, Colombia (Acta No. 146 of 30/08/2011) and the Ethical Review Board of London School of Hygiene and Tropical Medicine (Ref. no. 6289).

Consent for publication

Not applicable.

\section{Competing interests}

The authors declare that they have no competing interests.

\section{Author details}

${ }^{1}$ Faculty of Science and Technology, Norwegian University of Life Sciences, Ås, Norway. ${ }^{2}$ Instituto de Salud y Ambiente, Universidad El Bosque, Bogotá, Colombia. ${ }^{3}$ SARChl, Institute for Water and Waste Water Technology, Durban University of Technology, Durban, South Africa. ${ }^{4}$ MRC Tropical Epidemiology Group, London School of Hygiene and Tropical Medicine, London, UK. 
Received: 1 February 2017 Accepted: 17 July 2017

Published online: 27 July 2017

\section{References}

1. Gubler DJ. Dengue, urbanization and globalization: the unholy trinity of the 21st century. Trop Med Health. 2011;39(Suppl 4):3-11.

2. WHO: Prevention of sexual transmission of Zika virus interim guidance update 6 September 2016, WHO/ZIKV/MOC/16.1 Rev.3. 2016.

3. Bhatt $\mathrm{S}$, Gething PW, Brady OJ, Messina JP, Farlow AW, Moyes $\mathrm{CL}$, et al. The global distribution and burden of dengue. Nature. 2013;496:504-7.

4. WHO: Global strategy for dengue prevention and control, 2012-2020. World Health Organization. Geneva: WHO/HTM/NTD/NEM/2012.52012.

5. WHO: Zika situation report. Zika virus, Microcephaly, Guillain-Barré syndrome. Edited 10 March 2017. WHO, http://www.who.int/emergencies/ zika-virus/situation-report/en/. Accessed May 2017.

6. WHO: Chikungunya, Fact sheet. Updated April 2017. Edited by WHO 2017, http://www.who.int/mediacentre/factsheets/fs327/en/. Accessed May 2017.

7. Restrepo Jaramillo BN. Infección por el virus del Chikungunya. CES Med. 2014;28(2):313-23.

8. Schmidt WP, Suzuki M, Thiem VD, White RG, Tsuzuki A, Yoshida LM, et al. Population density, water supply, and the risk of dengue fever in Vietnam: cohort study and spatial analysis. PLoS Med. 2011;8(8):e1001082.

9. Vong S, Khieu V, Glass O, Ly S, Duong V, Huy R, et al. Dengue incidence in urban and rural Cambodia: results from population-based active fever surveillance, 2006-2008. PLoS Negl Trop Dis. 2010;4(11):e903.

10. Troyes L, Villegas Z, Troyes M. Expansión del Aedes aegypti a localidades rurales de Cajamarca. Rev Perú Med Exp Salud Pública. 2006;23:163-7.

11. Instituto Nacional de Salud: Informe Quincenal Epidemiológico Nacional (IQEN). 17 (16). 30 de Agosto de 2012. http://www.ins.gov.co/iqen/IQUEN/ IQEN\%20vol\%2017\%202012\%20num\%2016.pdf. Accessed May 2017.

12. Padilla JC, Rojas DP, Sáenz-Gómez R. Dengue en Colombia: Epidemiología de la reemergencia a la hiperendemia. Primera edición. Guías de Impresión Ltda: Bogotá, Colombia; 2012.

13. Diaz-Nieto LM, Macia A, Perotti MA, Beron CM. Geographical limits of the southeastern distribution of Aedes aegypti (Diptera, Culicidae) in Argentina. PLoS Negl Trop Dis. 2013;71:e1963.

14. Guagliardo SA, Barboza JL, Morrison AC, Astete H, Vazquez-Prokopec G, Kitron U. Patterns of geographic expansion of Aedes aegypti in the Peruvian Amazon. PLoS Negl Trop Dis. 2014;8(8):e3033.

15. Olano VA, Matiz Ml, Lenhart A, Cabezas L, Vargas SL, Jaramillo JF, et al. Schools as potential risk sites for vector-borne disease transmission: mosquito vectors in rural schools in two municipalities in Colombia. J Am Mosq Control Assoc. 2015;31(3):212-22.

16. Perez-Castro R, Castellanos JE, Olano VA, Matiz MI, Jaramillo JF, Vargas SL, et al. Detection of all four dengue serotypes in Aedes aegypti female mosquitoes collected in a rural area in Colombia. Memorias do Instituto Oswaldo Cruz. 2016;111(4):233-40.

17. Harrington LC, Scott TW, Lerdthusnee K, Coleman RC, Costero A, Clark GG, et al. Dispersal of the dengue vector Aedes aegypti within and between rural communities. Am J Trop Med Hyg. 2005:72(2):209-20.

18. Ingram DD, Franco SJ. 2013 NCHS urban-rural classification scheme for counties. Hyattsville, Maryland: U.S. Department of Health and Human Services, Centers for Disease Control and Prevention, National Center for Health Statistics; 2014. Accessed May 2017

19. WHO/UNICEF: Progress on Drinking Water and Sanitation - 2014 update. WHO/UNICEF Joint Monitoring Programme for Water Supply and Sanitation. World Health Organization and UNICEF. 2014. http://www.wssinfo.org/ fileadmin/user_upload/resources/JMP_report_2014_webEng.pdf. Accessed May 2017.

20. Walker ED, Lawson DL, Merritt RW, Morgan WT, Klug MJ. Nutrient dynamics, bacterial populations, and mosquito productivity in tree hole ecosystems and microcosms. Ecology. 1991;72(5):1529-46.

21. Romero-Vivas C, Arango-Padilla P, Falconar A. Pupal-productivity surveys to identify the key container habitats of Aedes aegypti (L.) in Barranquilla, the principal seaport of Colombia. Ann Trop Med Parasitol. 2006;100:S87-95.

22. Tinker M, Olano V. Ecología del Aedes aegypti en un pueblo de Colombia, Sur América. Biomédica. 1993;13:5-14.

23. Barrera R, Amador M, Clark GG. Ecological factors influencing Aedes aegypti (Diptera: Culicidae) productivity in artificial containers in Salinas, Puerto Rico. J Med Entomol. 2006;43(3):484-92.
24. Barrera R, Amador M, MacKay AJ. Population dynamics of Aedes aegypti and dengue as influenced by weather and human behavior in San Juan, Puerto Rico. PLoS Negl Trop Dis. 2011;5(12):e1378.

25. Vezzani D, Velazquez SM, Schweigmann N. Seasonal pattern of abundance of Aedes aegypti (Diptera: Culicidae) in Buenos Aires City, Argentina. Memorias Inst Oswaldo Cruz. 2004;99(4):351-6

26. Quintero J, Carrasquilla G, Suarez R, Gonzalez C, Olano VA. An ecosystemic approach to evaluating ecological, socioeconomic and group dynamics affecting the prevalence of Aedes aegypti in two Colombian towns. Cad Saude Publica. 2009;25(Suppl. 1):S93-103.

27. Sommerfeld J, Kroeger A. Eco-bio-social research on dengue in Asia: a multicountry study on ecosystem and community-based approaches for the control of dengue vectors in urban and peri-urban Asia. Pathog Global Health. 2012;106(8):428-35

28. Espinoza Gomez F, Hernandez Suarez CM, Coll CR. Factors that modify the larval indices of Aedes aegypti in Colima, Mexico. Rev Panam Salud Publica. 2001;10(1):6-12.

29. Tun-Lin W, Kay BH, Barnes A. The premise condition index: a tool for streamlining surveys of Aedes aegypti. Am J Trop Med Hyg. 1995;53(6):591-4

30. UNICEF/WHO: Progress on sanitation and drinking water - 2015 update and MDG assessment. Geneva: United Nations Children's Fund and World Health Organization; 2015. Accessed May 2017.

31. Ruiz-Lopez F, Gonzalez-Mazo A, Velez-Mira A, Gomez GF, Zuleta L, Uribe S, et al. Presence of Aedes (Stegomyia) aegypti (Linnaeus, 1762) and its natural infection with dengue virus at unrecorded heights in Colombia. Biomedica. 2016;36(2):303-8.

32. Quintero J, Brochero H, Manrique-Saide P, Barrera-Perez M, Basso C, Romero $\mathrm{S}$, et al. Ecological, biological and social dimensions of dengue vector breeding in five urban settings of Latin America: a multi-country study. BMC Infect Dis. 2014;14:38.

33. Alcalá L, Quintero J, González-Uribe C, Brochero H. Productividad de Aedes aegypti (L.) (Diptera: Culicidae) en viviendas y espacios públicos en una ciudad endémica para dengue en Colombia. Biomedica. 2015;35(2):258-68.

34. Ministerio de la Protección Social: Gestión para la vigilancia entomológica y control de la transmisión del dengue. Bogota, Colombia: Ministerio de la Protección Social - Instituto Nacional de Salud; 2014.

35. Bentley MD, Day JF. Chemical ecology and behavioral aspects of mosquito oviposition. Annu Rev Entomol. 1989:34:401-21.

36. Chitolina RF, Anjos FA, Lima TS, Castro EA, Costa-Ribeiro MC. Raw sewage as breeding site to Aedes (Stegomyia) aegypti (Diptera, culicidae). Acta Trop. 2016;164:290-6.

37. Beserra EB, Fernandes CR, Sousa JT, Freitas EM, Santos KD. The effect of water quality in the life cycle and in the attraction for the egg oviposition of Aedes aegypti (L.) (Diptera: Culicidae). Neotrop Entomol. 2010;39(6):1016-23.

38. Focks D, Alexander N. Multicountry study of Aedes aegypti pupal productivity survey methodology: findings and recommendations. vol. TDR/ IRM/DEN/06.1. Geneva: Special Programme for Research and Training in Tropical Diseases (TDR), World Health Organization; 2006: 48.

39. Lenhart AE, Castillo CE, Oviedo M, Villegas E. Use of the pupal/ demographic-survey technique to identify the epidemiologically important types of containers producing Aedes aegypti (L.) in a dengue-endemic area of Venezuela. Ann Trop Med Parasitol. 2006;100:S53-S9.

40. Fay RW, Perry AS. Laboratory studies of ovipositional preferences of Aedes aegypti. Mosq News. 1965;25:276-81.

41. Allan SA, Kline DL. Larval rearing water and preexisting eggs influence oviposition by Aedes aegypti and Aedes albopictus (Diptera: Culicidae). J Med Entomol. 1998;35(6):943-7.

42. Gonzalez PV, Gonzalez Audino PA, Masuh HM. Oviposition behavior in Aedes aegypti and Aedes albopictus (Diptera: Culicidae) in response to the presence of heterospecific and conspecific larvae. J Med Entomol. 2016; 53(2):268-72.

43. Chadee DD, Corbet PS, Greenwood JJD. Egglaying yellow fever mosquitoes avoid sites containing eggs laid by themselves or by conspecifics. Entomol Exp Appl. 1990;57:295-89.

44. Merritt RW, Dadd RH, Walker ED. Feeding behavior, natural food, and nutritional relationships of larval mosquitoes. Annu Rev Entomol. 1992;37:349-76.

45. Walker ED, Olds EJ, Merritt RW. Gut content analysis of mosquito larvae (Diptera: Culicidae) using DAPI stain and epifluorescence microscopy. J Med Entomol. 1988;25(6):551-4.

46. Briegel H. Metabolic relationship between female body size, reserves, and fecundity of Aedes aegypti. J Insect Physiol. 1990;36(3):165-72. 
47. Haramis L. Larval nutrition, adult body size, and the biology of Aedes triseriatus. In: Ecology of mosquitoes: Proceedings of a workshop: January 9-12, 1984. Vero Beach, Florida: Florida Medical Entomology Laboratory; 1985. p. 431-7.

48. Sumanochitrapon W, Strickman D, Sithiprasasna R, Kittayapong P, Innis BL. Effect of size and geographic origin of Aedes aegypti on oral infection with dengue-2 virus. Am J Trop Med Hyg. 1998;58(3):283-6.

49. Scott TW, Amerasinghe PH, Morrison AC, Lorenz LH, Clark GG, Strickman D, et al. Longitudinal studies of Aedes aegypti (Diptera: Culicidae) in Thailand and Puerto Rico: blood-feeding frequency. J Med Entomol. 2000;37(1):89-101.

50. Darriet F, Corbel V. Attractive properties and physicochemical modifications of water following colonization by Aedes aegypti larvae (Diptera: Culicidae). CR Biol. 2008;331(8):617-22. (In French)

51. DANE. Departamento Administrativo Nacional de Estadistica, (DANE). 2014. Proyecciones de población 2005-2020. https://www.dane.gov.co/index.php/ estadisticas-por-tema/demografia-y-poblacion/proyecciones-de-poblacion. Accessed May 2017

52. DANE: Cartilla de Conceptos Básicos e Indicadores Demográficos. Departamento Administrativo Nacional de Estadística (DANE), Colombia. 2007. http://www.dane.gov.co/files/etnicos/cartilla_quibdo.doc http://www. dane.gov.co/files/inf_geo/4Ge_ConceptosBasicos.pdf. Accessed May 2017.

53. DANE: Perfil municipal Anapoima, Cundinamarca. Bogotá, Colombia. 2010. Departamento Administrativo Nacional de Estadística. Boletín censo general. 2005. https://www.dane.gov.co/files/censo2005/PERFIL_PDF_CG2005/ 25035T7T000.PDF. Accessed May 2017.

54. Brooker S, Bethony J, Rodrigues L, Alexander N, Geiger S, Hotez P. Epidemiological, immunological and practical considerations in developing and evaluating a human hookworm vaccine. Expert Rev Vaccines. 2005;4(1):35-50.

55. Forattini OP. Entomologia médica, vol. 2. São Paulo, Brazil: Faculdade de Higiene e Saúde Pública; 1965.

56. González R, Darsie R Jr. Clave ilustrada para la determinación genérica de larvas de Culicidae de Colombia y el nuevo mundo. Bol Mus Entomol Univ Valle. 1996:4(1):21-37.

57. Lane J. Neotropical Culicidae. Volumes 1-2. Sao Paulo, Brazil: Universidade de Sao Paulo; 1953. 548 pp.

58. APHA/AWWA/WPCF. Standard Methods for the Examination of Water and Wastewater. 20th ed. Washington DC: America Public Health Association, American Water Works Association and Water Pollution Control Federation; 1998.

59. Kumar A, Sharma SK, Padbidri VS, Thakare JP, Jain DC, Datta KK. An outbreak of dengue fever in rural areas of northern India. J Commun Dis. 2001;33(4):274-81.

60. Phuanukoonnon S, Mueller I, Bryan JH. Effectiveness of dengue control practices in household water containers in Northeast Thailand. Tropical Med Int Health. 2005;10(8):755-63.

61. Maciel-de-Freitas R, Marques WA, Peres RC, Cunha SP, de Oliveira RL Variation in Aedes aegypti (Diptera: Culicidae) container productivity in a slum and a suburban district of Rio de Janeiro during dry and wet seasons. Mem Inst Oswaldo Cruz. 2007;102(4):489-96

62. Arunachalam N, Tana S, Espino F, Kittayapong P, Abeyewickreme W, Wai KT, et al. Eco-bio-social determinants of dengue vector breeding: a multicountry study in urban and periurban Asia. Bull World Health Organ. 2010;88(3):173-84.

63. Ferdousi F, Yoshimatsu S, Ma E, Sohel N, Wagatsuma Y. Identification of essential containers for Aedes larval breeding to control dengue in Dhaka. Bangladesh Trop Med Health. 2015;43(4):253-64.

64. WHO: Dengue - Guidelines for diagnosis, treatment, prevention and control. Geneva: World Health Organization; 2009.

65. Fernandez EA, Leontsini E, Sherman C, Chan AS, Reyes CE, Lozano RC, et al. Trial of a community-based intervention to decrease infestation of Aedes aegypti mosquitoes in cement washbasins in El Progreso, Honduras. Acta Trop. 1998;70(2):171-83.

66. Quintero J, Garcia-Betancourt T, Cortes S, Garcia D, Alcala L, Gonzalez-Uribe C, et al. Effectiveness and feasibility of long-lasting insecticide-treated curtains and water container covers for dengue vector control in Colombia: a cluster randomised trial. Trans R Soc Trop Med Hyg. 2015;109(2):116-25.

67. Deborah CE. Water quality assessments: a guide to use of biota, sediments and water in environmental monitoring. 2nd ed. London: Published on behalf of UNESCO/WHO/UNEP. E\&FN Spon; 1996.

68. Kent R, Belitz K. Concentrations of dissolved solids and nutrients in water sources and selected streams of the Santa Ana Basin, California, October 1998-September 2001. Sacramento: US geological survey, water-resources investigations report 03-4326; 2004.
69. Chatterjee S, Chakraborty A, Sinha SK. Spatial distribution \& physicochemical characterization of the breeding habitats of Aedes aegypti in and around Kolkata, West Bengal, India. Indian J Med Res. 2015;142(Suppl):S79-86.

70. Ma M, Huang M, Leng P. Abundance and distribution of immature mosquitoes in urban rivers proximate to their larval habitats. Acta Trop. 2016;163:121-9.

71. Wetzel R. Limnology: Lake and river ecosystems. 3rd ed. Edn. San Diego, CA: Academic Press; 2001.

72. Muturi EJ, Mwangangi J, Shililu J, Jacob BG, Mbogo C, Githure J, et al. Environmental factors associated with the distribution of Anopheles arabiensis and Culex quinquefasciatus in a rice agro-ecosystem in Mwea, Kenya. J Vector Ecol. 2008;33(1):56-63.

73. Irving EC, Liber K, Culp JM. Lethal and sublethal effects of low dissolved oxygen condition on two aquatic invertebrates, Chironomus tentans and Hyalella azteca. Environ Toxicol Chem. 2004;23(6):1561-6.

74. Burke R, Barrera R, Lewis M, Kluchinsky T, Claborn D. Septic tanks as larval habitats for the mosquitoes Aedes aegypti and Culex quinquefasciatus in Playa-Playita, Puerto Rico. Med Vet Entomol. 2010;24(2):117-23.

75. Gopalakrishnan R, Das M, Baruah I, Veer V, Dutta P. Physicochemical characteristics of habitats in relation to the density of container-breeding mosquitoes in Asom, India. J Vector Borne Dis. 2013;50(3):215-9.

76. Sardiñas Peña O, García Melían M, Castillo I, Fernández NM. [Physicochemical evaluation of the water from reservoirs positive to Aedes aegypti foci.] Rev Cubana Hig Epidemiol. 2008;46(2):1-6. (In Spanish)

77. Bhattacharya S. P. B. The southern house mosquito, Culex quinquefasciatus: profile of a smart vector. J Entomol Zool Stud. 2016;4(2):73-81.

78. Glossary of Meteorology: Urban Heat Island. American Meteorological Society. http://glossary.ametsoc.org. Accessed 30 Dec 2016.

79. Tun-Lin W, Burkot TR, Kay BH. Effects of temperature and larval diet on development rates and survival of the dengue vector Aedes aegypti in north Queensland, Australia. Med Vet Entomol. 2000;14(1):31-7.

80. Marinho RA, Beserra EB, Bezerra-Gusmao MA, Porto Vde S, Olinda RA, Dos Santos CA. Effects of temperature on the life cycle, expansion, and dispersion of Aedes aegypti (Diptera: Culicidae) in three cities in Paraiba, Brazil. J Vector Ecol. 2016;41(1):1-10.

81. Eisen L, Monaghan AJ, Lozano-Fuentes S, Steinhoff DF, Hayden MH, Bieringer PE. The impact of temperature on the bionomics of Aedes (Stegomyia) aegypti, with special reference to the cool geographic range margins. J Med Entomol. 2014;51(3):496-516.

82. Alto BW, Juliano SA. Temperature effects on the dynamics of Aedes albopictus (Diptera: Culicidae) populations in the laboratory. J Med Entomol. 2001;38(4):548-56

83. Alto BW, Juliano SA. Precipitation and temperature effects on populations of Aedes albopictus (Diptera: Culicidae): implications for range expansion. J Med Entomol. 2001;38(5):646-56.

84. Ponnusamy L, Xu N, Nojima S, Wesson DM, Schal C, Apperson CS. Identification of bacteria and bacteria-associated chemical cues that mediate oviposition site preferences by Aedes aegypti. Proc Natl Acad Sci USA. 2008;105:9262-7.

\section{Submit your next manuscript to BioMed Central and we will help you at every step:}

- We accept pre-submission inquiries

- Our selector tool helps you to find the most relevant journal

- We provide round the clock customer support

- Convenient online submission

- Thorough peer review

- Inclusion in PubMed and all major indexing services

- Maximum visibility for your research

Submit your manuscript at www.biomedcentral.com/submit 